Ristekdik (Jurnal Bimbingan dan Konseling)

Vol.6, No.2, 2021, hlm.195-201

DOI: http://dx.doi.org/10.31604/ristekdik.2021.v6i2.195-201

ISSN 2541-206X (online)

ISSN 2527-4244 (cetak)

\title{
HUBUNGAN SPIRITUAL QUOTIENT DENGAN KONTROL DIRI NARAPIDANA
}

\author{
${ }^{1}$ Annisa Fourkhani, ${ }^{2}$ Kusmiyanti \\ ${ }^{1,2}$ Politeknik Ilmu Pemasyarakatan \\ annisa.fourkhani@gmail.com
}

\begin{abstract}
The target of this study was to find out the relationship between spiritual quotient and self-control inmates at the Class IIA Purwokerto Penitentiary. In this case the researcher wants to know the value of the closeness of a relationship in each variable. This study utilizes descriptive statistical quantitative research as a research method where the data source comes from a statement questionnaire given to 87 research samples. Prisoners are the population used by taking samples through probability sampling technique with a simple random category. The results show that there is a strong positive relationship between spiritual quotient and self-control of prisoners with a correlation coefficient of 0.701. This means that the better the spiritual quotient, the better the self-control in prisoners.
\end{abstract}

Keywords: spiritual quotient, self control, prisoner.

\begin{abstract}
Abstrak: Target penelitian ini adalah mencari tahu keterkaitan antara spiritual quotient dengan kontrol diri narapidana di Lembaga Pemasyarakatan Kelas IIA Purwokerto. Dalam hal ini peneliti ingin mengetahui nilai keeratan suatu hubungan dalam setiap variabel. Penelitian ini memanfaatkan penelitian kuantitatif statistik deskriptif sebagai metode penelitian dimana sumber datanya berasal dari angket pernyataan yang diberikan kepada 87 sampel penelitian. Narapidana merupakan populasi yang digunakan dengan mengambil sampel melalui teknik sampling probabilita dengan kategori simpel random. Hasil memperlihatkan ada hubungan positif kuat antara spiritual quotient dengan kontrol diri dari narapidana dengan nilai koefisien korelasi 0,701 . Artinya semakin baik spiritual quotient semakin baik pula kontrol diri dalam diri narapidana.
\end{abstract}

Kata kunci: spiritual quotient, kontrol diri, narapidana

\section{PENDAHULUAN}

Indonesia memegang peranan yang penting sebagai penyelenggara keadilan karena Indonesia merupakan negara hukum.. Maknanya hukum memiliki kekuasaan tertinggi dan setiap warga negara Indonesia memiliki kewajiban menegakkan hukum dan berhak atas persamaan hak antara hukum dan pemerintah. Sebagai negara yang berlandaskan hukum, artinya segala tatanan kehidupan dalam bernegara dan bermasyarakat harus dilaksanakan berdasar atas hukum dimana keseluruhan sistem harus dilakukan berpedoman dengan perundang - undangan yang berlaku dan akan diberikan hukuman bagi setiap orang yang bersalah. Setiap warga negara yang bersalah akan menjalani proses peradilan pidana berawal dari penahanan hingga berakhir di lembaga pemasyarakatan dan menjalani masa pidananya. Lembaga pemasyarakatan menjadi tempat berakhirnya segala proses peradilan pidana sebagai penampung bagi pelaku tindak pidana yang sudah mendapat putusan inkrah untuk menjalani pemidanaan. 
Kehidupan dalam lembaga pemasyarakatan sebagai narapidana tentunya harus mengikuti dan mentaati peraturan yang ada di dalam lembaga pemasyarakatan. Karena jumlah narapidana yang banyak, tentunya tidak akan terlepas dari permasalahan keamanan dan ketertiban, mulai dari kerusuhan sampai pelarian. Lembaga pemasyarakatan perlu memiliki peraturan ketat yang secara khusus untuk membentuk narapidana yang disiplin dan memiliki kecerdasan spiritual. Dalam menjalani masa pidananya tentunya narapidana memiliki ruang gerak terbatas dimana ada banyak peraturan yang harus dijalani dan akan ada sanksi bagi narapidana yang melanggar peraturan. Kemampuan mengontrol diri harus tertanam dalam diri narapidana untuk menghindari perbuatan melanggar peraturan di dalam lembaga pemasyarakatan. Menurut Goleman (1999), kecerdasan emosional mengacu pada kecakapan mengenali perasaan diri sendiri dan orang lain, kesanggupan memotivasi diri sendiri, dan kapabilitas mengelola emosi dengan baik ketika berhubungan dengan diri sendiri dan orang lain. Orang dengan pengendalian diri yang baik biasanya termotivasi oleh intelektual yang lebih tinggi. Tentunya dengan intelektual spiritual yang lebih mumpuni, seseorang mampu mengatur dirinya sendiri. Orang dengan kecerdasan mental yang baik cenderung lebih diam dalam ketenangan dan terfokus mencari solusi dalam masalah dan bencana daripada egois (Krishna, 2017).
Menurut Danah Zohar dan Ian Marsall, Spiritual Quotient adalah kemampuan merencah dan menemukan solusi suatu permasalahan mengenai nilai dan moral, yaitu intelektual yang meletakkan sikap dan kehidupan setiap diri dalam arti yang lebih leluasa dan berlimpah, serta digunakan untuk membandingkan tingkah laku atau kehidupan setiap orang, kepiawaian untuk membandingkan jika perbuatan atau perjalanan hidup diri sendiri lebih memiliki banyak arti dibandingkan dengan yang lain. Kebijaksanaan spiritual adalah kebijaksanaan jiwa dimana mampu membantu manusia menyembuhkan dan membangun kecerdasan secara keseluruhan (Danah Zohar, 2001).

Lembaga Pemasyarakatan Kelas IIA Purwokerto memiliki jumlah penghuni per April 2021 dengan total 647. Banyaknya jumlah penghuni yang berasal dari berbagai macam daerah menimbulkan perbedaan suku, agama, ras dan budaya yang dapat memicu konflik. Suatu ancaman dan permasalahan tidak dapat terhindarkan di seluruh lapas maupun rutan. Perlunya pencegahan sejak dini untuk menghindari ancaman kerusuhan yang ada di dalam lapas maupun rutan. Memperketat peraturan merupakan upaya lembaga pemasyarakatan menghindari terjadinya pelanggaran dan kerusuhan di dalam intermal lembaga pemasyarakatan. Setiap tindakan selalu dimulai dengan niat dari dalam benak hatinya, dan hati adalah inti kecerdasan spiritual. Dalam hal ini, penulis ingin mencoba menguji keterkaitan antara Spiritual Quotient dan 
kontrol diri narapidana guna menghadapi aturan dan kondisi yang ada di Lembaga Pemasyarakatan Kelas IIA Purwokerto.

\section{METODE}

Penelitian dalam hal ini menggunakan metode kuantitatif melalui tipe statistik deskriptif. Tipe ini dipilih karena dianggap tepat untuk diterapkan dalam penelitian yang akan dilakukan mengenai hubungan spiritual quotient dengan kontrol diri narapidana di Lapas Kelas IIA Purwokerto. Penelitian ini dilakukan dengan membagikan kuesioner dengan total 87 responden. Sampel diambil menggunakan teknik sampling probabilita dengan kategori simple random. Dalam penelitian ini skala banyaknya sampel dihitung dengan memanfaatkan rumus slovin.

$$
n=\frac{N}{N\left(d^{2}\right)+1}
$$

\section{Keterangan :}

$\mathrm{N}=$ Skala Populasi

$\mathrm{n}=$ Skala sampel

$\mathrm{d}=$ ambang batas kesalahan, pada penelitian ini digunakan sebesar $10 \%$ atau dapat diartikan 0,01.

Variabel yang digunakan adalah variabel terikat dan variabel bebas. Variabel terikat/dependen disini berarti adalah variabel yang dipengaruhi dan variabel bebas/independen di sini berarti variabel yang mempengaruhi. Variabel independen pada penelitian ini adalah Spiritual Quotient dan variabel dependennya atau yang dipengaruhi adalah kontrol diri. Dari variable tersebut kemudian diturunkan menjadi dimensi atau indikator dimana variable Spiritual Quotient terdiri dari tujuh dimensi dan terbagi menjadi 21 item atau butir pernyataan, sedangkan untuk variable kontrol diri terdiri dari empat dimensi dan terbagi menjadi 17 pernyataan. Untuk mengetahui keterkaitan dua variabel yang bisa dicari dengan melihat dari hasil korelasi koefisian yang dapat membuktikan ada hubungan kuat dan lemahnya antarvariabel. Peneliti memanfaatkan penghitungan melalui koefisien korelasi yang dikembangkan oleh Pearson dengan aplikasi SPSS.

Hipotesis yang digunakan disini yaitu:

H0 : Tidak terdapat hubungan antara Spiritual Quotient dengan kontrol diri narapidana.

H1 : Terdapat hubungan hubungan antara Spiritual Quotient dengan kontrol diri narapidana.

\section{HASIL}

Target penelitian ini adalah untuk mencari tahu keterkaitan dua variabel yaitu Spiritual Quotient dengan kontrol diri narapidana dengan melihat hasil yang didapatkan sebagai berikut:

A. Uji Validitas

Uji ini dilakukan dengan instrumen Spiritual Quotient dan Kontrol Diri dengan bantuan program SPSS. Hasil uji validitas menunjukkan 21 item variabel Spiritual Quotient dan 17 item variabel Kontrol diri dianggap valid dengan nilai r-hitung $>\mathrm{r}$ tabel $(0,213)$ 
B. Uji Reliabilitas

Reliabilitas diuji demi mengetahui kesesuaian pernyataan jika digunakan dalam penelitan yang sejenis dengan waktu dan tempat yang berbeda. Data dikatakan reliabel dipandang dari skala koefisien Cronbach Alpha jika skala Cronbach Alpha $>0,60$. Dari hasil pengitungannya diketahui hasil sebagai berikut:

Tabel 1. Uji Reliabilitas Spiritual Quotient

\begin{tabular}{|c|c|}
\hline \multicolumn{2}{|c|}{ Reliability Statistics } \\
\hline $\begin{array}{c}\text { Cronbach's } \\
\text { Alpha }\end{array}$ & N of Items \\
\hline .856 & 21 \\
\hline
\end{tabular}

Tabel 2. Uji Reliabilitas Kontrol Diri

\begin{tabular}{|c|c|}
\hline \multicolumn{2}{|c|}{ Reliability Statistics } \\
\hline $\begin{array}{c}\text { Cronbach's } \\
\text { Alpha }\end{array}$ & N of Items \\
\hline .862 & 17 \\
\hline
\end{tabular}

Dapat kita lihat dari hasil uji reliabilitas pada 21 butir pernyataan variabel $\mathrm{X}$ (table 1) dan 17 butir pernyataan variabel Y (table 2) terlihat bahwa keduanya memiliki nilai Cronbach Alpha melebihi dari 0,60. Artinya butir - butir pernyataan dianggap reliabel dan dapat dijadikan sebagai instrumen penelitian untuk penelitian berikutnya.

C. Uji Normalitas

Tabel 3. Uji Normalitas

\begin{tabular}{|c|c|c|}
\hline \multicolumn{2}{|l|}{ One-Sample Kolmogorov-Smirnov Test } \\
\hline \multicolumn{2}{|c|}{} & $\begin{array}{c}\text { Unstandardized } \\
\text { Residual }\end{array}$ \\
\hline $\mathrm{N}$ & 87 \\
\hline $\begin{array}{c}\text { Normal } \\
\text { Parameters }\end{array}$ & Mean & .0000000 \\
\cline { 2 - 3 } & $\begin{array}{c}\text { Std. } \\
\text { Deviation }\end{array}$ & 5.20567769 \\
\hline Most Extreme & Absolute & .062 \\
\hline
\end{tabular}

\begin{tabular}{|l|l|l|}
\hline Differences & Positive & .045 \\
\cline { 2 - 3 } & Negative & -.062 \\
\hline \multicolumn{2}{|c|}{ Test Statistic } & .062 \\
\hline \multicolumn{2}{|c|}{ Asymp. Sig. (2-tailed) } & $.200^{\mathrm{c}, \mathrm{d}}$ \\
\hline
\end{tabular}

Tabel Tests Of Normality menunjukkan hasil uji Kolmogorov-Smirnov pada data Spiritual Quotient dan Kontrol Diri diketahui nilai signifikansinya adalah $0,200>0,05$. Pada nilai signifikansi terdapat huruf "d" yang artinya batas bawah dari nilai signifikansi yang benar adalah Sig $>\alpha$, maka dapat dikatakan data yang didistribusikan bersifat normal.

D. Uji Homogenitas

Tabel 4. Uji Homogenitas

Test of Homogeneity of Variances

\begin{tabular}{|c|c|c|c|c|}
\hline & $\begin{array}{c}\text { Levene } \\
\text { Statistic }\end{array}$ & $\mathrm{df1}$ & $\mathrm{df2}$ & Sig. \\
\hline Kontrol_Diri & .756 & 20 & 52 & .750 \\
\hline
\end{tabular}

Dari tabel diatas dapat kita lihat skala signifikansi melebihi dari 0,05 yang berarti data dinyatakan homogen.

E. Uji Linearitas

Tabel 5. Uji Linearitas

ANOVA Table

\begin{tabular}{|c|l|l|c|}
\hline \multicolumn{2}{|c|}{} & Sig. \\
\hline $\begin{array}{c}\text { Kontrol_Diri * } \\
\text { Spiritual_Quotient }\end{array}$ & $\begin{array}{l}\text { Between } \\
\text { Groups }\end{array}$ & (Combined) & .001 \\
\cline { 3 - 4 } & & $\begin{array}{l}\text { Linearity } \\
\text { feviation } \\
\text { from } \\
\text { Linearity }\end{array}$ & .000 \\
\cline { 3 - 4 } & Within Groups & \\
\cline { 2 - 4 } & Total & \\
\hline
\end{tabular}

Berdasarkan tabel output SPSS hasil uji linearitas menyatakan skala besaran signifikan deviation from linearity senilai 
0,966. Skala ini melebihi 0,05 yang artinya dua variable pada uji ini memiliki hubungan yang linear.

F. Analisis Koefisien Korelasi

Tabel 6. Koefisien Korelasi

\begin{tabular}{|l|l|c|c|}
\hline \multicolumn{4}{|c|}{ Correlations } \\
\hline \multicolumn{2}{|c|}{} & $\begin{array}{c}\text { Spiritual_Q } \\
\text { uotient }\end{array}$ & Kontrol_Diri \\
\hline \multirow{2}{*}{$\begin{array}{l}\text { Spiritual_ } \\
\text { Quotient }\end{array}$} & $\begin{array}{l}\text { Pearson } \\
\text { Correlation }\end{array}$ & 1 & $.701^{* *}$ \\
\cline { 2 - 4 } & Sig. (2-tailed) & & .000 \\
\cline { 2 - 4 } & N & 87 & 87 \\
\hline \multirow{2}{*}{$\begin{array}{l}\text { Kontrol_D } \\
\text { iri }\end{array}$} & $\begin{array}{l}\text { Pearson } \\
\text { Correlation }\end{array}$ & $.701^{* *}$ & 1 \\
\cline { 2 - 4 } & Sig.(2-tailed) & .000 & \\
\cline { 2 - 4 } & N & 87 & 87 \\
\hline
\end{tabular}

Berdasarkan tabel korelasi diatas yang merupakan penghitungan dengan menggunakan SPSS dapat terlihat bahwa nilai korelasi antara Spiritual Quotient dengan Kontrol diri sebesar 0,701 yang artinya ada hubungan yang positif yang dominan atau kuat. Hal ini menyatakan bahwa semakin kuat nilai spiritual quotient pada narapidana maka semakin baik pula narapidana dalam mengontrol dirinya.

\section{PEMBAHASAN}

Melihat hasil penelitian yang dilakukan peneliti diatas dengan jumlah responden sebanyak 87 orang narapidan yang berada di Lembaga Pemasyarakatan Kelas IIA Purwokerto tentang hubungan spiritual quotient dengan control diri narapidana dapat kita ketahui sebagai berikut:

1. Uji validitas yang dilakukan berdasarkan pada penghitungan SPSS data dinyatakan valid dengan variabel independen Spiritual Quotient dengan 21 pernyataan dan variabel dependen kontrol diri dengan 17 pernyataan.

2. Uji reliabilitas memperlihatkan skala signifikansi dengan skala spiritual quotient sebesar 0,856 pada 21 item dan 0,862 pada 17 item yang berarti bahwa data dianggap reliabel sehingga bisa digunakan untuk penelitian berikutnya.

3. Uji normalitas dapat kita lihat nilai pada tabel diatas sebesar 0,200. Hal ini membuktikan bahwa data yang diambil peneliti terdistribusikan secara normal.

4. Uji Homogenitas memperlihatkan skala signifikan dari Levene Statistic sebesar 0,750 . Skala ini lebih dari nilai 0,05 . Hal ini membuktikan bahwa $\mathrm{H} 0$ ditolak dan $\mathrm{H} 1$ diterima. Tujuan dilakukan uji ini yaitu untuk mencari tahu apakah data bersifat homogen atau sebaliknya. dengan tujuan untuk mengetahui apakah data bersifat homogen atau tidak. Homogenitas data adalah satu dari beberapa syarat yang dijalankan dalam uji secara statistik.

5. Uji linearitas pada tabel di atas memperlihatkan angka deviation from linearity sebesar 0,966. Uji ini dilakukan untuk mencari ada tidaknya keterkaitan atau hubungan yang signifikan antar kedua variabel. Dengan melihat angka pada data tersebut membuktikan bahwa kedua variabel memiliki hubungan atau keterkaitan yang linear.

6. Analisis koefisien korelasi pada tabel di atas memperlihatkan skala nilai 0,701 , membuktikan bahwa ada 
hubungan/keterkaitan yang sifatnya positif

kuat antar variabel.

Pada bagian analisis koefisien korelasi dapat kita ketahui hasilnya sebesar 0,701. Hasil ini menunjukkan adanya nilai signifikansi yang cukup besar dengan $70,1 \%$. Artinya ada keterkaitan hubungan kuat yang positif antara variabel spiritual quotient dengan variabel kontrol diri. Hasil ini membuktikan bahwa H0 ditolak dan $\mathrm{H} 1$ diterima yang dibuktikan melalui hasil koefisien korelasi dengan aplikasi SPSS.

Hasil memperlihatkan bahwa ada keterkaitan hubungan antara Spiritual Quotient dengan Kontrol Diri. Dilihat dari nilai koefisien korelasinya menunjukkan adanya keterkaitan yang kuat antar variabel tersebut. Menurut Danah Zohar dan Ian Marsall, kecerdasan mental adalah dasar dari Intelligence Quotient dan Emotional Quotient (termasuk kontrol diri).

Nilai kecerdasan psikis memberi seseorang pengendalian diri untuk menghadapi berbagai situasi. Orang masih bisa ambisius, egois, dan tidak sabar. Akan tetapi memiliki kecerdasan spiritual memungkinkan seseorang membatasi diri lebih jauh dan mencegah mereka melakukan perilaku berbahaya. Daniel Goleman mengatakan sulit untuk mengendalikan emosi yang keluar ketika kita tidak mampu mengendalikan emosi dalam diri. Namun, ketika seseorang mampu mencapai kecerdasan spiritual dan berupaya dalam meningkatkannya, mereka dapat mengendalikan emosinya (kontrol diri).

\section{SIMPULAN}

Berdasarkan uraian diatas dapat kita simpulkan ialah ada hubungan dan keterkaitan yang sifatnya positif kuat antar dua variabel Spiritual Quotient dengan variabel Kontrol Diri pada Narapidana di Lembaga Pemasyarakatan Kelas IIA Purwokerto. Hal ini menyatakan bahwa semakin baik Spiritual Quotient yang ada pada narapidana semakin baik pula tingkat narapidana dalam menahan diri (kontrol diri) menyikapi peraturan yang terdapat di Lembaga Pemasyarakatan Kelas IIA Purwokerto.

\section{DAFTAR RUJUKAN}

Alkautzar, A. M. (2018). Hubungan Kecerdasan Emosional, Kecerdasan Spiritual Dan Regulasi Diri Dalam Belajar (SelfRegulated Learning) Terhadap Hubungan Kecerdasan Emosional, Kecerdasan Spiritual Dan Regulasi Diri Dalam Belajar (Self-Regulated Learning) Terhadap Hasil Ujian OSCA. Journal of Islamic Nursing, 3(1), 9-19.

Anwar, M. A., Gani, Aa. M. O., \& Rahman, M. S. (2020). Effects of spiritual intelligence from Islamic perspective on emotional intelligence. Journal of Islamic Accounting and Business Research, 11(1), 216-232. https://doi.org/10.1108/JIABR-10-20160123

Akhtar, S., Arshad, M. A., Mahmood, A., \& Ahmed, A. (2017). Spiritual quotient towards organizational sustainability: the Islamic perspective. World Journal of Entrepreneurship, Management and Sustainable Development, 13(2), 163170. https://doi.org/10.1108/wjemsd-012017-0002

Azouzi, M. A., \& Jarboui, A. (2013). CEO emotional intelligence and board of directors' efficiency. Corporate Governance (Bingley), 13(4), 365-383. https://doi.org/10.1108/CG- 10-2011$\underline{0081}$ 
Creswell, John W. (2014). RESEARCH DESIGN. Pendekatan Metode Kualitatif, Kuantitatif dan Campuran. Edisi Keempat. Pustaka Belajar

Husna, T. A., Mayangsari, M. D., \& Rachmah, D. N. (2018). Peranan Kecerdasan Spiritual Terhadap Regulasi Diri Martapura. Jurnal Ecopsy, 5(1), 51-55. https://ppjp.ulm.ac.id/journal/index.php/ ecopsy/article/viewFile/4885/4243

Ni, Putu, R., Luh, Kade, D., \& I Made, Wianto, P. (2017). Pengaruh Kecerdasan Intelektual, Kecerdasan Emosional dan Kecerdasan Spiritual terhadap Sikap Etis Mahasiswa S1 Akuntansi pada Universitas di Bali. Jurnal Krisna, 9(1), 50-56.

Puji Lestari, S. M., Triwahyuni, T., Utari, E., \& Fatimah, N. (2020). Hubungan Kecerdasan Spiritual terhadap Self Regulated Learning (SRL) pada Mahasiswa Fakultas Kedokteran Umum Universitas Malahayati Angkatan 2018. ANFUSINA: Journal of Psychology, 3(1), 85-96. https://doi.org/10.24042/ajp.v3i1.6042

Salehi, M., Ali Mirzaee, M., \& Yazdani, M. (2017). Spiritual and emotional intelligences, financial performance, tax avoidance and corporate disclosure quality in Iran. International Journal of Law and Management, 59(2), 237-256. https://doi.org/10.1108/IJLMA-112015-0059

Vasconcelos, A. F. (2020). Spiritual intelligence: a theoretical synthesis and work-life potential linkages. International Journal of Organizational Analysis, 28(1), 109-134. https://doi.org/10.1108/IJOA-04-20191733 